\title{
ELECTROFORMING: ITS PRESENT STATUS AND INNOVATIVE APPLICATIONS FOR CLEAN TECHNOLOGY AND MICROMANUFACTURE
}

\author{
ELEKTROFORMOWANIE: STAN OBECNY I INNOWACYJNE \\ ZASTOSOWANIA W OBSZARZE CZYSTYCH TECHNOLOGII \\ I W MIKROWYTWARZANIU
}

\author{
Joseph A. McGEOUGH ${ }^{1}$
}

\begin{abstract}
Electroforming is a form of electroplating in which free-standing finely formed items can be manufactured to precise detail. It has been adapted to produce thin iron and steel sheet from recycled scrap steel. It can be used to manufacture electrodes in copper for electrodischarge machining (EDM). Its combination with lithography (LIGA) has seen it being increasingly used for micromechanical systems (MEMS).
\end{abstract}

Keywords: electroforming, electroplating, electrode for EDM

Streszczenie: Elektroformowanie jest formą elektroplaterowania, w której wolnostojące drobne elementy mogą być obrabiane z dużą dokładnością. Proces ten został przystosowany m.in. do produkcji cienkich blach żelaznych i stalowych. Elektroformowanie stosowane jest również do produkcji miedzianych elektrod wykorzystywanych w procesie obróbki elektroerozyjnej (EDM). Proces elektroformowania $\mathrm{w}$ połączenie $\mathrm{z}$ procesem litografii w jednym cyklu wytwarzania - LIGA (Lithographic Galvanoforming Abforming) znajduje coraz szersze zastosowanie w masowej produkcji mikrosystemów elektromechanicznych (MEMS).

Słowa kluczowe: elektroformowanie, wytwarzanie elektrod, obróbka elektroerozyjna

\section{INTRODUCTION}

In electroforming, metal is electrolytically deposited upon the metallic cathode of an electrochemically polarized cell. The process therefore resembles electroplating with three distinct differences:

- much thicker deposited coatings are applied,

\footnotetext{
${ }^{1}$ Institute for Integrated Micro \& Nano Systems, School of Engineering, The University of Edinburgh, The King's Buildings, Edinburgh, EH9 3JL, U.K.
} 
- after deposition, the metallic coating is removed by mechanical, chemical or even thermal methods in order to yield a free-standing structure or "electroform"

- the surface features of the cathode on which the metal is deposited are reproduced on the surface of the electroformed component. [1,2,3].

The third feature means that the cathode, or mandrel, is first prepared with the subsequent shape required, and can be used repeatedly to produce a large number of electroformed articles.

This high degree of dimensional accuracy that can be achieved repeatedly (often to less than $5 \mu \mathrm{m}$ ) makes electroforming attractive for applications such as die and mould manufacture.

The surface detail on the mandrel can also be achieved on the electroform: to about $0.01 \mu \mathrm{m}$ is typical. This feature, and its ability to produce a complex shape in a single operation provides electroforming with strong advantages over conventional processes which would otherwise require a series of procedures such as machining, deburring, and pressing.

Electroformed products can range in size from millimetres $(\mathrm{mm})$ to metres $(\mathrm{m})$. The only limitation is usually capacity of the electroplating plant: size of the electrolyte tank, and of the mandrels that can be produced, and appropriate voltage supplies; providing these criteria can be met, the mass production of components can be achieved, and the same electrolyte solution throughout without waste; an environmental attraction. Recently attention has been drawn to electroforming of composite materials. Inevitably like other unconventional manufacturing methods electroforming has its drawbacks. Brittleness, oxidation and internal stress mean that copper, iron and nickel are usually the only materials that are electroformed, although recent attempts have been made to achieve alloy electroforming. Indeed internal stress remains a serious obstacle to the wider use of electroforming as it leads to cracking and peeling. Pulsed voltage systems, electrolyte additives that reduce internal stress are amongst the methods used to combat internal stress. Another disadvantage can be non-uniform thickness of the electroform, a consequence of the potential distribution in the electrochemical cell between the mandrel, and anode. Auxiliary anodes are sometimes inserted into the cell in order to direct the current towards area of the mandrel so that a uniform thickness for the electroform can be achieved.

Possibly the greatest drawback is lengthy times of electroforming that are needed to produce the items needed. The ways of reducing these times can be parallel production lines or increasing electrolyte agitation (velocity) to increase the current density needed for deposition [4].

\section{MODELLING OF THE ELECTROFORMING PROCESS}

The electroforming process can be readily modelled by seeking analytic solutions to three main equations [5]. Firstly Laplace's equation has to be solved to predict the potential between the cathode and anode electrodes of the electroforming cell, and especially at the cathode where metal is deposited. Ohm's law can then be used to find the current density at the cathode mandrel surface. Finally, Faraday's law is employed to determine the rate of metal deposition, that is, electroforming.

These powerful methods are best solved computationally, although analytic solutions are available. They all have to take into account the influence of current efficiency which plays a key role in electroforming, and its relationship to the aqueous electrolyte solutions that are 
chosen. Overpotentials at the electrodes also have a major effect in contributing to conditions for a uniform thickness for the electroform.

When these computational conditions are adopted, conditions whereby periodic reversal of polarity is used to achieve a uniform thickness of electroform can be found. The polarity cycle is made up of a period of deposition, then a shorter time of dissolution, (the current efficiency for the former being lower than that for the latter) overpotentials are claimed also have a part, although difficult to identify. Through an appropriate series of cycles a uniform thickness of electroform is then obtained. Computational methods can be employed to indicate the right choice of electrolyte solution needed.

Sometimes Direct Current (DC) is used instead of periodic reversal of current, particularly when a uniform thickness is not the requirement, but when the upper face of the electroformed layer has to be flat, with the lower face still adopting the surface finish, texture and profile of the mandrel. These conditions can also be analysed by use of the three governing equations discussed above.

Finally, shaped anodes are sometimes used to yield a uniform thickness for the electroform. These anodes normally have a form which replicates that of the mandrel. By this procedure a uniform current density over the mandrel is obtained. When this anode is insoluble, the electrolyte solutions has to be maintained with metal salts, so that its electrochemical properties (e.g. pH) are maintained. Alternatives soluble anodes can be used; the simulation exercise now has to take into account how their change in shape affects the metal deposition process.

\section{APPLICATIONS OF ELECTROFORMING}

\subsection{FOIL (THIN IRON/STEEL SHEET)}

By recycling of waste steel (dissolving in hydrochloric acid to produce aqueous ferrous chloride electrolyte solution), electroforming has been performed by use of a rotating cathode drum. Thin iron foil, of thickness about $0.1 \mathrm{~mm}$, can be produced which is cheaper than conventionally rolled think steel sheet, yet with comparable mechanical properties [6]. Electroformed copper foil is used extensively for printed circuit boards. Nickel foil similarly produced also finds application for circuit boards.

\subsection{MESH PRODUCTS}

Electroforming has wide applications for filters, sieves and electric razor foils $[2,4]$.

\subsection{Compact (CD) and Video Discs}

Production of these items relies heavily on electroforming, under clean room conditions for example for manufacture of helical tracks $0.1 \mu \mathrm{m}$ deep and $0.6 \mu \mathrm{m}$ wide. The foundations of this technology lie in well-established precision electroforming for record stampers. In its use for manufacture of $\mathrm{CD}$ discs, the audio recording source material is prepared into a premastered digital format. The latter is then played into a mastering system; a laser beam recorder is used to cut away peaks and valleys (lands and pits) into a defined surface, that is coated onto a glass master substrate. Nickel is then plated onto the glass master to create a negative impression (the so-called "father"). The father can then be used to mould discs 
(usually for short production runs). Positive impressions "mothers" can also be manufactured, which in turn are used to produce negative-impression nickel moulds, or "stampers". The latter are fitted into the cavity of an injection moulding machine. Polycarbonate resin is next injected into the mould cavity. A positive impression of the "lands" and "pits" is produced on one of its sides of the plastic disc, formed from the solidified resin. On metallisation of the disc surface, a playback laser can be used to "read" the CD [7].

\subsection{LIGA}

"LIGA" is an acronym for the mass-production process that has to encorporate electroforming, lithography and plastic moulding.

In lithography, pre features are defined onto a substrate. Optical, electron and ion beam and $\mathrm{X}$-ray and other lithographic methods are all used, in the reproduction of a three-dimensional resist.

When mass manufacture of ceramic and other components is required, electroforming is used to fill in the resist structure. The negative pattern of the (plastic) structure is generated as a secondary structure out of metals such as nickel, copper, and other alloys. It can be used to make tools for plastic moulding. Typical dimensions are: structural height above one $\mathrm{mm}$, lateral dimensions to $0.2 \mu \mathrm{m}$, surface roughness of $30 \mathrm{~nm}$.

\subsection{MEMS (MICROELECTROMECHANICAL SYSTEMS)}

Miniaturisation involving $\mathrm{mm}$ to micron size structures with micron to nanometre tolerance can be achieved by LIGA-based processes with the electroforming (or electroplating) being used to produce layers thicker than PVD or CVD (Physical or Chemical Vaopur Deposition) (up to 10 to $1000 \mu \mathrm{m}$ ) [7].

\subsection{STEREOLITHOGRAPHY AND SOLID FREE FORM (SPF) FABRICATION WITH ELECTROFORMING}

The increasingly complexity of electrodischarge machined (EDM) tools for die and moulds has led to increasing use of Rapid Prototyping (RP) linked to electroforming. From a CAD model of the tool shape required an STL file format is produced. The file is inputted into a RP machine to build the electroform master, which is metallised, and placed in a electroplating solution. Metal is deposited on the master when the required electroform thickness is obtained, the master is removed from the metal shell, which becomes the EDM electrode.

\section{CONCLUSIONS}

Electroforming is finding fresh relevance as environmentally friendly process as a clean technology in what waste metals can be recovered to produce low cost thin metal sheet. Its combination with new irradiation techniques such as lithography and stereolithography and solid free form has led to its new processes for micro and nano-related processes such as LIGA, MEM and micromanufacture. 


\section{REFERENCES}

[1] FINNISTON M., Phil Trans Roy Soc, Vol, 275, 1973, pp. 313-327.

[2] McGEOUGH J.A., Electroforming, Chapter 6479. CIRP Encyclopaedia of Production Engineering, Springer, 2014.

[3] McGEOUGH J.A., LEU M.C., RAJURHAR K.P., DE SLIVA A.K.M., LIU Q., Electroforming Process and Applications to Micro/Macro Manufacture. Annals of Int. Acad. for Prod. Eng. (CIRP), Vol. 50, Part 2, 2001 p. 499-514.

[4] McGEOUGH J.A., RASMUSSEN H., Theoretical Analysis of the Electroforming Process Journal of Mechanical Engineering Science, Vol. 23, No. 3, pp. 1981, 113-120.

[5] SOLE M.J., Electroforming: Methods, Materials and Merchandise. Minerals, Materials and Merchandise, Vol. 46, 1994, pp. 29-35.

[6] SPIRO P., Electroforming: A Comprehensive Survey of Theory, P \{ractice and Commercial Applications. Teddington, Draper (Publisher), 1968.

[7] THOMS S., MACINTYRE D., High Resolution Lithography, Chapter 12, pp. 325-368, in Micromachining of Engineering Materials (Ed. J.A. McGeough), Taylor Francis (former Marcel Dekker Publisher), New York.

[8] WATSON S.A., WORN D.K., Development in Electroforming of Nickel for Engineering Applications. Metallurgist and Materials Technology, Vol. 13, 1981, pp. 310-314. 